University for Business and Technology in Kosovo

UBT Knowledge Center

UBT International Conference

2012 UBT International Conference

Nov 2nd, 9:00 AM - Nov 3rd, 5:00 PM

\title{
The Role of Business in Local Economic Development
}

\author{
Ylldeze Sokoli \\ University of Vlora, ylldezesokoli@hotmail.com \\ Lavdosh Zaho \\ University of Tirana, lavdoshz@gmail.com
}

Follow this and additional works at: https://knowledgecenter.ubt-uni.net/conference

Part of the Business Commons

\section{Recommended Citation}

Sokoli, Ylldeze and Zaho, Lavdosh, "The Role of Business in Local Economic Development" (2012). UBT International Conference. 60.

https://knowledgecenter.ubt-uni.net/conference/2012/all-events/60

This Event is brought to you for free and open access by the Publication and Journals at UBT Knowledge Center. It has been accepted for inclusion in UBT International Conference by an authorized administrator of UBT Knowledge Center. For more information, please contact knowledge.center@ubt-uni.net. 


\title{
The Role of Business in Local Economic Development
}

\author{
Ylldeze Sokoli', Lavdosh Zaho ${ }^{2}$ \\ ${ }^{I}$ Faculty of Economy, University of Vlora "Ismail Qemali", Republic of Albania \\ ylldezesokoli@hotmail.com \\ ${ }^{2}$ Faculty of Economy, University of Tirana, Republic of Albania \\ lavdoshz@gmail.com
}

\begin{abstract}
Small business is backbone of national economy. The base of economic system is free enterprise. Small business is attractive because of a greater independence and better financial income. Small business development is essential element for economic development of a country. One of the most important duties of government is to create a suitable economic and politic environment, which allows the creation and development of small businesses. The tax system is very important for local government. The new fiscal packet offered to the local government a substantial fiscal autonomy, allowing the growth of local budget. Following the collapse of the centralized economy system in Albania, also opened the way for business development. Business in Albania was supported by many Western foreign loans. Because of the existing structure in place and financial opportunities to people was conducted mainly small businesses. Later in a long time, with the development of economy and business was conducted moving from small businesses in those medium and large ones. Revenues from taxes and fees make up the bulk of their source of income including taxes and small business. Increased decentralization is very important for current conditions and development of Albania and alleviates some problems bad enough to knock as government and not good management of income.
\end{abstract}

Keywords: small business, tax, local government, local income, economic development 